\title{
Mimesis and Metaphor: The biosemiotic generation of meaning in Cassirer and Uexküll
}

\author{
Andreas Weber \\ Friedhofsweg 11a, D-21614 Buxtehude \\ Hamburg, Germany \\ e-mail: frankandreasweber@gmx.de
}

\begin{abstract}
In this paper I pursue the influences of Jakob von Uexküll's biosemiotics on the anthropology of Ernst Cassirer. I propose that Cassirer in his Philosophy of the Symbolic Forms has written a cultural semiotics which in certain core ideas is grounded on biosemiotic presuppositions, some explicit (as the "emotive basic ground" of experience), some more implicit. I try to trace the connecting lines to a biosemiotic approach with the goal of formulating a comprehensive semiotic anthropology which understands man as embodied being and culture as a phenomenon of general semioses.
\end{abstract}

\section{Introduction}

Together with Jakob von Uexküll there was another important semiotician teaching in Hamburg in the twenties and thirties of the past century: Ernst Cassirer. Like Uexküll's, Ernst Cassirer's role as a major contributor to semiotics has only recently been understood in all its breadth. Cassirer's work has been influential in the theory of art and aesthetics (Langer 1953; 1979; 1967-1983; Goodman 1997), in ethnology (Geertz 1997), in cultural philosophy and epistemology (Schwemmer 1997) and other areas.

Uexküll had argued that organisms perceive their worlds as signs; their realities are constructed from meanings. Cassirer, however, had proposed that humans perceive their worlds through symbols - there is no experience possible outside the various symbolic forms, as there are myth, religion, art, science. I want to analyze some of the philo- 
sophical relationships between Uexküll and Cassirer. Both thinkers knew each other and also repeatedly met in academic circles. Some statements of great mutual respect have been recorded (Heusden 2002). But there is first of all a marked influence which Uexküll's thinking left on Cassirer's late works, particularly in the Essay on Man (1944).

I will concentrate on one topic in the relationship between the two thinkers which can be considered important for both of them: the connection between a cultural semiotics, which is Cassirer's Philosophy of Symbolic Forms, and a biosemiotic theory. The major problem for such a synthesis, which lies at the core of the twocultures-problem, is to show how culture emerges from or anchors in the body. Cassirer's reception of Uexküll can be said to be an attempt to solve this, to overcome the arbitrariness of an approach to man which is limited only to cultural phenomena. Cassirer takes even a kind of protobiosemiotic position when he explains how symbols are generated from human experience. Cassirer is not very explicit about this process, apart from in certain core passages of his Philosophy of Symbolic Forms. It is particularly these arguments which need biosemiotic analysis. To provide this is the aim of the present paper.

Cassirer's main interest was not biological meaning generation. He adopts biological findings because he needs what he thinks of as a "vitalist" scheme of the living to justify his cultural semiotics (Heusden 2002; Cassirer 1944). Cassirer had to legitimize the fact that he took culture to be the defining character of man. "Vitalism" hence is the prerequisite to Cassirer's culturalism, because the former is an emergentist paradigm: if the living system can be described as emerging from matter arranged in a particular way, it could mean that the symbolic universe emerges from a specifically fitted animal, Homo sapiens.

But even here Cassirer's understanding of Uexküll, though decisive for a new framing of his cultural philosophy, does not fathom out the real depth of semiotic possibilities which a biological explanation of meaning can provide. Paradoxically, Cassirer has become relatively famous because the references to body and organism are so scarce in his work. He seemed to have written an anticipation of contemporary semiotics, the symbolic forms being somewhat similar to the much more recent argument that everything is "discourse". 
But, as certain crucial passages in his works show, the body or the basic emotive ground of experience, as Cassirer expresses himself - plays a major, though hidden, role in the making of the symbol. Cassirer tries to anchor his philosophy in the world of the living, even if he is not very explicit about it. It is for this reason that his philosophy is important today, at a time when the poststructuralist semiotic approach showing major methodological difficulties (Falck 1994; Latour 1995).

To strengthen this hypothesis we have to look for a deep relation between the concept of symbolic forms and a biosemiotic viewpoint. Here I will concentrate on Cassirer's idea of the process of how symbols are produced. This has always been the most critical and enigmatic part of the Philosophy of Symbolic Forms. But at the same time it is the key to it - and here Uexküll's work does enter.

\section{Kant's bold heirs}

The most striking similarity in Cassirer and Uexküll is their determination to continue the "critical business" of Immanuel Kant. It is interesting that this has also been the aim of the semiotician Charles Sanders Peirce - to complete what Kant had left open. To go over Kant's constructionism apparently leads to semiotics.

Cassirer and Uexküll start their projects on different levels of Kant's heritage. Uexküll tries to further analyze the biological functions as the source of the Kantian "conditions of possibility" of any perception. What is transcendental for Kant, for Uexküll is provided by the biological building plan of an organism. Uexküll thus creates a biological constructivism avant la lettre. Consequently, there is no longer a rational subject which maps its categories on an outside world. Any perceptional categories are related to the anatomy of the respective organism. They are the embodied process of cognition. Uexküll's new rationality is one of the building plan - hence a rationality which can not leave the body.

Cassirer, however, argues that Kant's faculties of human reason have to be completed by the symbolic forms of culture. Thus, similar to Uexküll, he introduces a stance of uncertainty, of contingency into the Kantian clarity. Culture is not purely rational, but, as we know, it is always entangled with situations; it is manifold, dense, even "dirty". 
In thus writing forth Kant, Cassirer already uses Uexküll's development of Kant's philosophy. In his anthropological summa, the Essay on Man, Cassirer introduces a "symbolic network", enlarging Uexküll's effector and receptor cycle, whereas Uexküll had also placed culture inside the biological functional circle. Cassirer opens the circle to encompass the symbolic faculty of man as a part of his biological layout - indeed, as a feature of his building plan.

Obviously, both semiotic approaches overcome problems that in the Kantian framework had remained difficult. Both stress the relativity of knowledge - one referring to cognition, the other to culture. But both approaches also contain their own gaps: for Uexküll, as for all constructivists, it is difficult to avoid a solipsistic stance. Why is any communication possible in the first place, if each individual is locked in its own "bubble" of perception, its own "Umwelt" (Uexküll 1980)? As we know, Uexküll had to introduce the rather cryptic "Naturplan" to explain the harmony of the living world.

Cassirer, on the other hand, has no problem with intersubjectivity. He can simply elucidate it as a central feature of symbolic forms. The semiosphere is the symbolic cosmos shared by all men. His difficulties are nevertheless also related to the problem of the external world. What mediates the entry of certain experiences into the symbolic realm? Why do specific symbols play a pertinent role in nearly all cultures - as do strong metaphors of nature, which are known from the most ancient cultures, but are still today commonly used in poetry? What Cassirer is missing in his theory of man as an "animal symbolicum" precisely is the animal. For this reason he is interested in Uexküll. And it is here where a further biosemiotic deepening can make Cassirer's already acclaimed philosophy still more important. We only have to follow the way he himself indicated: as Cassirer stresses, any critique of culture ultimately must be grounded on a critique of perception.

To meet the problems left open by Kant, we have to go beyond Uexküll and Cassirer. How does fully reflexive semioticity emerge from the organic realm? However, the leap Cassirer takes right into the symbolic universe does not have to be necessary any longer. As we know today, life is no mystery inside matter, but rather a lawful outcome of some of its special arrangements, permitted by them, though not caused. Symbolic behavior may then be a lawful stage of the same emergent process in just another magnitude (Weber, Varela 
2002). To explain the way in which symbolicity arises from biological meaning, Cassirer himself has contributed a good part of the map. To understand it, let us have a look at his conception of the making of symbolical value.

\section{Metaphor: Biosemiotic generation of the symbol in Cassirer}

A core term in Cassirer's philosophy is what he calls symbolische Prägnanz, "symbolic pregnance" (Innis 2001). It defines the process by which an outside factor or stimulus enters the symbolic universe of culture (Cassirer 1977-1982, vol. 3: 235). Symbolic pregnance is present in all strata of culture, but it is accessible most broadly in the "expressive function", which is the basic form of symbolisation. It can be found in myth, religion, and art: their expressive functions are the fires where living symbols are forged, where sense is extracted from experience.

Symbolic pregnance is possible because any sensual experience already provides its transformation into a symbol which perfectly fits to express the experience. Symbolism is a corporal matter. Things are experienced through sensory perception. Their symbolical value is their value for the experiencing body. So far, Uexküll and Cassirer's thinking is parallel. To understand Cassirer's switch to culture however, we have to look at what might be called "primordial" metaphors or symbols: gestures that arouse the same feeling as is felt in the original experience which they symbolize. Hence, in a primary process of symbol generation, experiences are what they mean. For Cassirer the symbolic understanding of the world is grounded on this basic emotional background, "gefühlsmäßiger Urgrund" as he puts it (Cassirer 1977-1982, vol. 2: 118). All experiences are valued as they carry gloomy or serene traits that immediately characterize their symbolic import. Cassirer calls this process an "Urphänomen", in reference to Goethe's holist theory of symbols.

We can see here a strong similarity between Cassirer's ideas and some core theses of Merleau-Ponty's phenomenology of perception: “'Semiosis' is here 'pushed down,' with an explicit reference to Cassirer, to the emergence of meaning in the perceptual field itself" (Innis 2001). The world has a physiognomic appearance before any 
interpretation takes place. It is coloured by a primary accent of value (Cassirer 1977-1982, vol. 2: 118f).

In the way Cassirer describes the working of this primary value he comes very close to the biosemiotic account of how meaning arises from a grid of signification which the cognising organism lays out onto the world. As Cassirer states:

Only those sensory experiences are extracted from the fluid stream of perception which somehow are shown to be related to the centres of will and of doing, which prove to be helping or hindering the whole of the living, which thus prove to be important and necessary. (Cassirer 1983: 106; my translation, A. W.)

This quotation shows Uexküll's influence in a much deeper way than Cassirer might have admitted. Cassirer speaks of sensory experiences and of the way they become valued as symbols. Already in his terminology he adopts a biosemiotic way of expression.

Most interestingly, Cassirer touches the question of value which a system exhibits in trying to keep alive (Weber, Varela 2002). The character of an experience is determined by what has been its embodied signification for an organism. The quality of this signification is dependent on whether the embodied interaction is good or bad. For a simple organism, we could even say, any experience is an Urphänomen. Any experience melts down to this universal existential coin of lived value, and is then paid back in due amount for the construction of the sign - or rather for that flash of insight, coupling existential value, or of vital import to the gestalt of the original situation. Here we can clearly see, that in the first stage of the symbolic process signs mean exactly what they really are for the organism.

To understand the process of meaning generation proposed by Cassirer we have to go back to the creation of meaning by the organism as such. Because of the living's incessant need of input to keep up the fragile equilibrium of Autopoiesis (Maturana, Varela 1980), stimuli gain an existential cognitive significance. This significance is represented to the organism as a perspective of existential concern. External influences hence act as signs that have a meaning for the organism's survival (for discussion see Weber 2001; 2002; 2003).

This sounds somewhat trivial, but it may mark also for man, as he is an embodied being, the crucial point where experiences become 
metaphors, and where the metaphor still has the gestalt of the experience that forged it. Think for example of the symbolic power of darkness, which really is a frightening situation for a daylight species like man. Darkness marks a family of metaphors which stand for the uncanny, for the gloomy aspects of the soul. The "Gestaltung", the form which the symbol will take, is the efficient form of experience which the human organism is undergoing.

In a manuscript, that has never been published, Cassirer discusses the symbolic worlds of certain animal species. Contrary to his statements in the Essay on Man, at least some seem to be fitted with a symbolic system which has a physiognomic character, as the mythic world order of early peoples had (Cassirer 1992). This idea contradicts the more elaborate (and "official") position in his Essay on man where he accepts a symbolic faculty solely for humans. But this finding stresses even more how important the relationship between "physiognomy", i.e. embodied experience, and the symbol was for Cassirer.

Following Cassirer, we might postulate a genealogy of meaning generation, starting with early human cultures. Their obsession with the facts of nature seems to indicate a state of "physiognomic character", where embodied experiences still are what they mean. As recent works (e.g., Morphy 1995) have shown, however, the semiotic universe of ancient peoples is rather complicated and at any rate not simpler than ours. Still (as another work would have to show), we might learn from this intricacy a lot more about the necessary interrelation between the experience of nature and its use to understand human social existence (Descola 1997; Ingold 2000): ancient cultures do not rest in an innocent "physiognomic" condition towards nature, but they show with very little "cultural noise" the interrelation of embodiment and symbolicity. Archaic cosmological systems are not paradigms for the lowest stage of symbolic forms. They nonetheless prove Cassirers link between embodiment and symbol in showing in a very clear way how the body (or nature) and symbol are intertwined.

\section{Mimesis: how new meaning arises from old bodies}

To understand symbolic pregnance, the body must be comprehended as the condition of the possibility of any expression. As such it lies at 
the base of any culture. This can be grasped more clearly if we regard how poetic metaphor recalls or even re-enacts primary symbols: it tries to arouse the same feeling by generating vital import (Langer 1953). Metaphorical truth, therefore, is far from being literal, but it has to obey the laws of organic flow and rest, the laws of need, of organic desire. A "warm smile" sends out energy by way of meaning, not as a fire does.

There is one fact central to this re-enactment of vital import: what is expressed in the symbol has real properties that cause its uncoupling from the foregoing situation. The metaphor, as a living one, is partly unchained from its pregnance and starts its own semiotic fecundity. This core phenomenon may account for the independency of culture in reference to its embodied origin. Metaphor entrains all its cultural background framework, but then in its primary core as vital import rolls back onto the subject with existential force. Obviously, an "as if" gesture can have the same import as the "real thing", or even more living in a family where nobody smiles can chill as much as the lack of heating can. The reason for this analogous effectiveness may be that all impressions enter the cognitive network melted down to a universal existential value, a kind of synaesthetic protostate (Weber 2003), where "real" and "virtual" is not differentiated, and "inside" and "outside" are not really clearly marked.

Here we have to introduce the concept of mimesis. This term can be defined as the interpretative reaction to a stimulus from the surrounding world, which leads to its mirroring with slight variation (cf. Gebauer, Wulf 2003). It is important to note that any gesture has a mimetic relationship to its meaning. Any gesture by living being is an interpretation of a sign and at the same time a new one. Meaning is thus an event which construes a new reality by the fact of expressing or enacting its signifying value. It happens on a middle ground, being at the same time new and known, incorporating old, but also calling forth new meanings. Because a symbol is always a gesture in its own right, it always remains at some final point an enigma too.

By this definition, most organic cognition is mimetic, because it is the interpretation of a sign. This inevitably leads to a cascade of related form in the interpretation. The signified is contained in the sign as an analogous form, not as an abstract code. The track is new, but at the same time it is the hollow form which contains the step. To come back to Goethe and his notion of the Urphänomen in general poiesis, 
that of art and that of the living: when Goethe is proposing that the eye is sun-like, "sonnenhaft", he does not mean that the eye is designed for sunlight — but that in receiving light it somehow mirrors its action by mimetic shape. It interprets the fact that there is light by its own action of shining.

If we look at poetry again, we might retain a glimpse of what is the enigmatic differentia specifica of the animal symbolicum seen under an embodied-subject view. The deciding moment in the symbolic (or poetic) achievement, the so called "keen metaphor" (Haverkamp 1995), is that it does not only arouse a vital import through the synaesthetic enactement of feeling: it produces something entirely new, something never heard of, which becomes an opaque part of the world itself. Maybe this is the alter in the middle of the idem. What I propose as human specific difference, then, is not the sole fact that humans use symbols, but their increase in poietic power: reinforced creation.

The symbol jumps over the blind spot of cognition with a flash of unexpected light. It knows more than what it was borrowed for. Its wisdom stems from a double source, always merging body and culture: the symbol is filled with the embodied wisdom of primary metaphor, and at the same time it brings with itself the material of a whole culture, the unfathomed depth of the semiotic system. Following Paul Valéry, the symbol is the thou which knows of me what I cannot see, but what, for exactly this reason, brings me to life in the first place.

We have to accept the independency of culture for the very reason that it is biologically based. A biological symbol always entrains the newness of the event, the continuing enactment, the absoluteness of interbeing which already presupposes the other in the building of self. From this standpoint we can come back to Cassirer and to his attempt to formulate the genesis of cultural symbols from an emotive base. For Cassirer, the relationship between body and soul — or culture - is symbolic: it is even the paradigmatic example for symbolicity. From here stems the permeability of body for cultural metaphor.

Biosemiotic mimesis in human terms means to be born in a world of both material meanings and of a priori nonmaterial significations. But with every breath both become part of enactive mimesis, of the interpretative re-enactment of the world. The resulting topography is the organism's own path: twirling lines where the silhouette of mountains and trees and the shaking and shivering of the moving spot become indistinguishable. 


\section{References}

Bundgaard, Peer F. 2002. Ernst Cassirer's theory of perception: Towards a geometry of experience. In: Foss, Gunnar; Kasa, Eivind (eds.), Forms of Knowledge and Sensibility: Ernst Cassirer and the Human Sciences. Kristiansand: HøyskoleForlaget, 149-182.

Cassirer, Ernst 1977-1982. Philosophie der symbolischen Formen. Darmstadt: Wissenschaftliche Buchgesellschaft.

- 1983 [1925]. Sprache und Mythos: Ein Beitrag zum Problem der Götternamen. In: Cassirer, Ernst, Wesen und Wirkung des Symbolbegriffs. Darmstadt: Wissenschaftliche Buchgesellschaft, 71-167.

- 1992 [1944]. An Essay on Man. New Haven: Yale University Press.

Descola, Philippe 1997. The Spears of twilight: Life and death in the Amazon jungle. London: Flamingo.

Falck, Colin 1994. Myth, Truth and Literature. Cambridge: Cambridge University Press.

Gebauer, Gunter; Wulf, Christoph 2003. Mimetische Weltzugänge: Soziales Handeln - Rituale und Spiele - ästhetische Produktionen. Stuttgart: Kohlhammer.

Geertz, Clifford 1997. Dichte Beschreibung: Beiträge zum Verstehen kultureller Systeme. Frankfurt am Main: Suhrkamp.

Goodman, Nelson 1997. Sprachen der Kunst. Frankfurt am Main: Suhrkamp.

Haverkamp, Anselm (ed.) 1995. Theorie der Metapher. Darmstadt: Wissenschaftliche Buchgesellschaft.

Heusden, Barend van 2002. Jakob von Uexküll and Ernst Cassirer. Semiotica 134(1/4): 275-292.

Ingold, Tim 2000. The Perception of the Environment. London: Routledge.

Innis, Robert E. 2001. Perception, interpretation, and the signs of art. The Journal of Speculative Philosophy 15(1): 20-32.

Knoppe, Thomas (ed.) 1992. Die theoretische Philosophie Ernst Cassirers: Zu den Grundlagen transzendentaler Wissenschafts- und Kulturtheorie. Hamburg: Meiner.

Lakoff, George; Johnson, Mark 1980. Metaphors We Live by. Chicago: University of Chicago Press.

- 1999. Philosophy in the Flesh. New York: Basic Books.

Langer, Suzanne K. 1953. Feeling and Form. New York: Scribner's.

- 1967-1983. Mind: An Essay on Human Feeling. (3 Bände.) Baltimore: Johns Hopkins University Press.

- 1979. Philosophie auf neuem Wege. Mittenwald: Mäander Kunstverlag.

Latour, Bruno 1995. Wir sind nie modern gewesen. Frankfurt am Main: Fischer.

Maturana, Humberto R.; Varela, Francisco J. 1980. Autopoiesis and Cognition: The Realization of the Living. Boston: D. Reidel.

Morphy, Howard 1995. Landscape and the reproduction of the ancestral past. In: Hirsch, Eric; O'Hanlon, Michael (eds.), The Anthropology of Landscape: Perspectives of Place and Space. Oxford: Clarendon,184-209.

Schwemmer, Oswald 1997. Ernst Cassirer: Ein Philosoph der europäischen Moderne. Berlin: Akademie-Verlag. 
Uexküll, Jakob von 1980. Kompositionslehre der Natur. Biologie als undogmatische Naturwissenschaft. Ausgewählte Schriften. (Herausgegeben und eingeleitet von Thure von Uexküll.) Frankfurt am Main: Ullstein Verlag.

Weber, Andreas 2001. Cognition as expression: The autopoietic foundations of an aesthetic theory of nature. Sign Systems Studies 29(1): 153-168.

- 2002. Feeling the signs: Organic experience, intrinsic teleology and the origins of meaning in the biological philosophy of Hans Jonas and Susanne K. Langer. Sign Systems Studies 30(1): 183-200.

- 2003. Natur als Bedeutung: Versuch einer semiotischen Theorie des Lebendigen. Würzburg: Königshausen und Neumann.

Weber, Andreas; Varela, Francisco J. 2002. Life after Kant: Natural purposes and the autopoietic foundations of biological individuality. Phenomenology and the Cognitive Sciences 1: 97-125.

\section{Мимезис и метафора: \\ биосемиотическое производство значения у Кассирера и Юкскюлла}

В статье рассматривается влияние юкскюлловской биосемиотики на антропологию Эрнста Кассирера. Утверждается, что “Философия символических форм” Кассирера написана как семиотика культуры, которая в некоторых своих основных идеях основывается на биосемиотических пресуппозициях, в одних случаях эксплицитно (как “эмоциональная основа” опыта), а в других — имплицитно. Выявляются черты, общие с биосемиотическим подходом, с целью сформулировать всеобъемлющую семиотическую антропологию, которая рассматривала бы человека как телесное существо и культуру как феномен всеобщего семиозиса.

\section{Mimees ja metafoor: Biosemiootiline tähendusloome Cassireril ja Uexküllil}

Vaatluse all on Jakob von Uexkülli biosemiootika mõjud Ernst Cassireri antropoloogiale. Väidan, et Cassireri "Sümboliliste vormide filosoofia" on kirjutatud kui kultuurisemiootika, mis oma teatud põhiliste ideede osas tugineb biosemiootilistele eeldustele, osalt otsesemalt (kui kogemuse “emotiivne alus"), osalt kaudsemalt. Püüan välja tuua ühendusjooni biosemiootilise lähenemisega, eesmärgiga formuleerida semiootilist antropoloogiat, mis mõistaks inimest kui kehandunud olendit ja kultuuri kui üldsemioosilist fenomeni. 